\title{
IMPROVING STUDENTS'S DESCRIPTIVE SPEAKING COMPETENCE BY USING CUE CARDS AT THE GRADE VIII 2 OF PUBLIC JUNIOR HIGH SCHOOL 03 BENGKULU CITY
}

\author{
Ruri Ariati \\ Syahrial \\ University of Bengkulu \\ Benglulu, Indonesia 38371 \\ Email : ariati_ruri@yahoo.co.id \\ Email : eric.syahrial@gmail.com
}

\begin{abstract}
This classroom action research was carried for implementing cue cards as the teaching media to improve students' descriptive speaking in class VIII 2 of SMPN 3 Bengkulu City. This research was focused on: (1) the improvement of students' descriptive speaking competence by using cue cards and (2) the investigation of factors involved in the improvement of students' descriptive speaking competence by using cue cards. This research was implemented to 36 students (19 female and 17 male) registered in this class. The progress was measured by speaking test and some supporting data such as observation checklist, field note, and interview. The result of the research indicated the progress of students' descriptive speaking by using cue cards. Students in this class were not good in speaking performances could be affected by the lack of other English skills. In action phase of the two cycles, students made a lot of mistakes in grammar and were lack of vocabulary mastery. The factors influenced in improving students' descriptive speaking competence were students' English proficiency: integrated skills and language element (pronunciation, grammatical comprehension, vocabulary mastery, and fluency), thinking ability, attitude along the treatment. The research concluded that the improvement did not achieve the level of satisfaction as expected. Secondly the factors influenced were integrated skills, language element, thinking ability and attitude.
\end{abstract}

\section{Keywords: Improving, Descriptive Speaking Competence, Cue Cards.}

\begin{abstract}
Abstrak: Penelitian tindakan kelas ini dilakukan untuk mengimplementasikan cue cards sebagai media ajar untuk meningkatkan kemampuan descriptive speaking siswa di kelas VIII 2 SMPN 3 Kota Bengkulu. Penelitian ini bertujuan untuk: (1) meningkatkan kemampuan descriptive speaking siswa melalui media ajar cue cards dan (2) mengidentifikasi faktor-faktor yang mempengaruhi peningkatan kemampuan descriptive speaking siswa melalui media ajar cue cards. Penelitian ini melibatkan 36 siswa (19 perempuan dan 17 laki-laki). Peningkatan kemampuan siswa diukur melalui speaking test dan data-data penunjang seperti observation checklist, field note, and interview. Hasil penelitian menunjukan ada peningkatan pada kemampuan descriptive speaking. Kemampuan speaking siswa masih rendah dipengaruhi oleh kurang penguasaan English skills yang lain. Selain itu pada tahap action di setiap siklus penelitian siswa banyak membuat kesalahan gramatikal dan kekurangan penguasaan kosa kata. Adapun faktorfaktor yang mempengaruhi peningkatan descriptive speaking siswa adalah English proficiency yang terdiri atas skills yang terintegrasi dan elemen-elemen bahasa lainnya
\end{abstract}


(pronunciation, grammatical comprehension, vocabulary mastery, dan fluency), serta kemampuan berpikir, dan sikap siswa selama penelitian berlangsung.

\section{Kata Kunci: Peningkatan, Kompetensi Descriptive Speaking, Cue Cards.}

\section{INTRODUCTION}

Mastering speaking in junior high school level still becomes the common problem found in Indonesia. This skill cannot be easily acquired by the learners as it is productive skill that consists of producing systematic verbal utterances to convey meaning (Nunan, 2003). In the implementation, this activity is different from other skills, reading for example, where process is only focusing on the transforming the written words into sound and readable words while speaking is an interactive process of conducting meaning that involves producing, receiving, and processing information (Brown, 2001; Nunan, 2003). Hence, the conditions of speaking to be done include of sharing idea and internalizing process of information.

The same problem happened in SMPN 03 Bengkulu city where only about $47 \%$ of 36 students of class VIII 2 could pass the passing grade $(7,00)$ in formative test, while the rest was failed. The low score of students' speaking test indicates the problems happened in acquiring speaking competence. Students faced inhibition in speaking English such as worry of making mistakes, fearful of criticism or losing face, and shy. Moreover, there were some complains from students that students cannot think of anything to say. The other problems were the lack of participation from the students or teacher domination and the mother-tongue use in speaking class byboth teacher and students.

Speaking activities in junior high school curriculum is developed based on the text types taught in classroom. One of them is descriptive text which is aimed to describe a particular person, place, or thing. Description consists of describing parts, qualities, characteristics. The linguistic feature occurs in this text is focused on specific participants, the use of attributive and identifying process, the frequent use of epithets and classifier in nominal groups, and the use of simple present tense. Moreover, significant grammatical features used is present tense which focuses on specific participants, descriptive adjectives, detailed noun phrase to give information about the subject, adverbials to give additional information about behavior, and figurative language (Budiastuti, 2007; Mursyid, 2011).

This concept of descriptive text is mostly transferred into speaking activities in the classroom. This activity is known as descriptive speaking. Descriptive speaking competence or descriptive speech is one of oral action that involves the ability to visualize the object of speaking through words. In the other words, it means narrating about an object, event, or phenomenon, so that the audience could visualize the image clearly. This activity refers to the process of providing a detailed, 
vivid, word picture of a person, animal, place, or object. Thus it is important for students to determine the characteristics, features, functions, or good points of the object of speaking. Furthermore, a descriptive speech normally contains instructions that may be useful to the audience. Topics represent a great variety of choice, namely, any memorable event, any place to visit, and any experience to be followed. Basic concepts are description, detailed instruction, piece of advice, useful recommendation. These conditions refer to the exclusiveness of topic choosing in descriptive speaking. The topic must be specific and related directly to the speaker.

Unfortunately, the facts showed that the students' lack of descriptive speaking competence became the most problem at school especially in Junior High School level. These all problems somehow caused by the inappropriate media used by teachers at class that cannot cover and develop students' speaking skill especially descriptive speaking competence appropriately. Thus, there must be a proper techniques and medium to teach descriptive speaking at class. Media are used to motivate students in learning beside interesting materials and teachers' competence in teaching. The proper media to stimulate students' eagerness must be related to material that included in curriculum, attracted and useful to help student easily to speak (Hamalik, 1998).

One best medium that can be used is cue card. Cue card is card with words or picture on it, which is used to encourage the students to respond (Harmer, 2001). This media is interesting, attractive, and easy to be made for both students and teacher. In addition, Cue Cards are also clearly visible, which can help the students to describe the object of speaking easily and to reduce preparation time (Hammer, 2001). Sets of pictures can be re-used; especially they can be laminated and are applicable at any level. The second advantage is that it could be used to tell stories in class and as one of the more popular ways to elicit oral language performance in both intensive and extensive levels (Brown: 2004).

However, selecting appropriate cue cards are important. Cue cards need to be appropriate not only for the purpose in hand but also for the classes they are being used for. If cards are too childish, the students may not like them. Second, cards should be visible and they have to be durable. Therefore, the use of cue cards has to consider the time, visibility, and significance in learning process (Harmer, 2001). Furthermore, some qualifications for precise cue cards were those pictures should be appropriate for the age and interest level of students. Pictures with characters should show real people rather than cartoon characters in order to ensure appropriate perception. Besides, the picture must be free of cultural bias and in the application, the teachers must give a sufficient time for students to examine, analyze and internalize the information given in the picture before speaking performance (O'Malley and Pierce, 1996). 
By the assumption on the lack of speaking ability of students and the effectiveness of cue cards, this research was aimed to investigate the use of cue cards in improving students' descriptive speaking competence. The study also identified the factors influenced in improving students' descriptive speaking competence by using cue cards. The previous research indicated the significant increasing score of speaking test among the students by using cue cards (Budiastuti, 2007). Researcher claimed some factors such an interesting style of learning and activeness of student increase along the research period. Furthermore, the same research done to students of SMP 15 Bandung showed that there was improvement of the students in producing spoken descriptive text in every cycle after using cue cards. In addition, the result of interview and observation sheet showed that cue card can be one of alternative media in teaching spoken descriptive text and it could encourage the students 'motivation in learning descriptive text. On the other hand, the researcher found some problems such as the limitation of time that became the disadvantages of using cue cards (Suryani, 2010).

First, this research hopefully could be useful for teachers to improve the condition of class and continually using this method as strategy to improve students' descriptive speaking competence. The second, students could use cue cards to help them to improve and explore the descriptive speaking competence. The last, for the next researchers, this research could be used as the reference for further research related to the topic.

\section{METHOD}

\section{Participants}

The participants of the research were students of $2^{\text {nd }}$ grade (class VIII 2) of SMPN 03 Bengkulu in Academic Year 2011/2012. The participants were 36 students consist of 17 male students and 19 female students. Acting as the collaborator to observe the teaching element from teacher point of view, the researcher got help from the English teacher, Eva Eliza, S.Pdi.

\section{Instruments}

The instruments of this research consisted of test, observation checklist, field notes and, interview. Test was divided into two kinds according to time of test given, pretest and post test. The test score would measure the baseline score of the pre-test and the progress score after the treatment or after the post test.

The next instrument was observation checklist; checklist for student and checklist for teacher. Students' checklist covered students' behavior that was able to be a supporting data for the test score while teacher's checklist covered many indicators focusing on teacher's approach in teaching and delivering the materials. Both checklists were provided by field notes to cover the implicit reasons of situation at class along the research.

The last instrument was interview given to both students and teacher. Researcher asked several questions about 
students' interest, motivation, background knowledge, favorite's skills, and difficulties in learning English. To teacher, the questions were about the experiences of teacher in teaching English in the class and basic condition of students in acquiring English.

\section{Procedures of The Research}

This study followed the form of Classroom Acton Research (CAR) which refers to the way of teacher collecting the data about the process of teaching, the way student accepts the material for effective teaching and learning strategy (Mills, 2007). The cycles were divided into four steps. The steps are planning, action, observation, and reflection (Kemmis, cited in O’Brien 1998).

\section{Planning}

In planning, information about students' difficulties in learning English was taken instruments and lesson plans were prepared.

\section{Action}

This step required researcher to act as the classroom teacher and implemented cue cards in class. The implementation of cue cards followed the lesson plan as following:

Before the pre activity conducted, the researcher distributed speaking pre-test to the students. This research was done in order to get the baseline data or score.

\section{$\checkmark$ Pre-activity}

Teacher started the class by checking the attendance list and introducing the materials of descriptive to students. Students were led to discuss about the descriptive materials such as the characteristic and generic structure of descriptive text. Then, teacher divided students into groups of five and work ingroup for the entire treatment.

\section{$\checkmark$ Main-activity}

In main activity, there was a set of cue cars related to the topic which was distributed to each other group. Students must discuss the cue card and try to describe the objects on the cue cards. Teacher determined some aspects that students must be focused on their description such as, the physical appearance (color, shape, sized), function, strength, weakness, advantages, or personal experiences between the students and object of speaking. After a while, researcher asked students to demonstrate the description of object in-group. Each student should take turn to describe at least one characteristic of the object. Further, one of representative of each group must present the whole description of the object to whole class.

\section{$\checkmark$ Closing-activity}

In closing activity, teacher strengthened the important points of the study. Students were asked to answer several questions related to the materials given that day. Both teacher and students also shared the difficulties for students along the teaching and learning process.

\section{Observation}

In this section collaborator critically checked whether teacher followed the steps in the lesson plans and took notes on teacher's and students' behavior. When some items were not stated in checklist observation, collaborator could write down in the field note. 


\section{Reflection}

This section described the result and effects of every step in the action phase. Those steps could cover the strength or weaknesses happened on each step of action. Then those results gathered by researcher and collaborator were compared. The result of students' test after Cue Cards treatment also became the indicator to measure the successful of the research. Observation was important as the basic step to lead the next cycles.

\section{FINDING}

\section{Cycle 1}

From the preliminary review done by the researcher, it was found that students' interest towards English was good with specification that most students like and enjoy studying English. Almost all students were keen on English. $50 \%$ of class population claimed the active participation in teaching and learning process. The rest of population seemed enjoy studying English but faced many troubles related to the lack of courage, knowledge about English and laziness. Most of students chose to be passive at class especially in speaking activity and decided that reading and answering questions in written text as the easiest and mostly applied in English class. The theme of cue cards used in lesson plans were: things around you, family, classroom activities, and daily activities.

In action, the researcher had done two meetings. Researcher acted as a teacher and started the class by introduction and explaining the descriptive text features. There were only five groups (28 students) in first meeting, because several students did not attend the class. The results in the first meeting were the students confused of working in group, students seemed not familiar with taking-turn in speaking activity, and some students thought that the task was paragraph construction. The class was so noisy and out of control. The mother tongue dominated the speaking activity. As the result, students played around with the cue cards and were not seriously joining the treatment.

There were six students absent on the second meeting. The number of group discussion was six groups (30 students). Students were easier to follow the class that day. The attitudes along the class were also better. The discussion could run well for a while, only few of students (male students) were not serious. However, in overall, students participation and motivation to speak English were quite increase. Students' interest could be shown by some questions related to pictures that could be answered. The crucial problems found were the mistakes and errors in grammar and wrong pronunciation. Besides that, limited vocabulary mastery affected negatively to students' speaking performance.

The observation was done along the first and second meetings. Collaborators took some notes and put thick on observation checklist. Collaborator suggested that researcher should not use full English along the teaching process, multiple pictures used in group discussion were too complicated, and class condition should be managed better. Observer also caught some 
good points and strengths. The good points were the clear instruction and strong voice, friendly and understandable explanation. While for students, the good attitudes, respect, and also cooperative along the class could be the good foundation for next treatment. After conducting 2 meetings, the post test was given to students. Cycle 1 post test asked students to describe 2 pictures in one time speaking performance.

By analyzing the students' behavior and performances, the collaborator suggested researcher to let students describe one picture only at one descriptive performance recording. This advice proposed to ease students to concentrate and focus to one cue card only so that the performance will be better. Researcher appreciated and agreed to use one cue card only at one descriptive speaking performance. From researcher attitude, observer advised researcher to be more patient to the less smart and lazy students. The second finding was students' lack of grammatical understanding on descriptive speaking features. The last point stressed by the researcher was students had limited vocabulary mastery. Those findings must be refined in the next cycle.

\section{Cycle 2}

There were some changes in procedures and lesson plan in cycle two. Researcher confirmed to collaborator and revised some useless actions or confusing instruction in explaining materials. Researcher was also challenged to provide the easiest way in explaining the grammatical order in constructing sentences in descriptive text.
Based on the discussion, researcher started the cycle 2 by explaining and correcting the students' grammatical mistakes and error in descriptive speaking.

The theme of cue cards was classroom activities and daily activities. Unlike in cycle 1 , researcher put more attention to correct students' grammatical mistakes and error. The use of full English in materials explanation was also minimized to easier students in acquiring the understanding. Students' attitudes in first meeting of cycle 2 were better and the group discussion ran well. Class control was also improved and the noisy was reduced smoothly. However, the domination of mother tongue could not be erased suddenly. It was very hard to create conducive class where English used as the main language.

Related to the cue cards complexity, students were exposed to be more aware to the physical appearances of the object in the cue cards. The vocabulary mastery had big influence in these two meetings. There were more physical aspects that must be concerned by students. In these two meetings, students looked more comfortable in expressing the idea in English in-group and group performance in front of class. Students also corrected the grammatical mistake one to another in-group. The cooperative work in group was also good. However students' capacity and capability in grammar and other skills were not sufficient. The integrated skills in English should be combined ultimately to support the speaking competence. 
Some notes taken by observer mostly concerned about students' behavior along the treatments. From teacher's performance, observed claimed that the use of bilingual and clear instruction were suitable. However, from students' side, there were some notes about unfair and dishonest of students' work. The activity focused on group discussion, so the individual work could not be seen well. In this cycle some students copied another students' sentence and did not feel confident to express the idea by themselves.
However, the good things after treatment can be proved by the students talked a lot in speaking activities, the participation was even and the motivation was high. So, the research still had good value and positive effect toward the improvement of students' descriptive speaking competence.

Along the treatment, speaking tests were given to students. The test score indicated progress with significant points as follow:

Table: 1 Speaking Score in Pre Test, Post Test in Cycle 1 and Post Test in Cycle 2

\begin{tabular}{|c|c|c|c|c|c|c|}
\hline Score Range & Pre Test & Students & $\begin{array}{c}\text { Post Test } \\
\text { Cycle 1 }\end{array}$ & Students & $\begin{array}{c}\text { Post Test } \\
\text { Cycle 2 }\end{array}$ & Students \\
\hline $0-20$ & $33 \%$ & 12 & $14 \%$ & 5 & $14 \%$ & 5 \\
\hline $21-40$ & $41 \%$ & 18 & $36 \%$ & 13 & $22 \%$ & 8 \\
\hline $41-60$ & $25 \%$ & 9 & $44 \%$ & 16 & $8 \%$ & 3 \\
\hline $61-80$ & - & - & $6 \%$ & 2 & $42 \%$ & 15 \\
\hline $81-100$ & - & - & - & - & $14 \%$ & 5 \\
\hline
\end{tabular}

$\mathrm{N}=36$ Students

The result showed that there were improvements in students' descriptive speaking performance in grade VIII 2 of SMPN 3 Bengkulu city. First improvement can be proved by the increasing score. This was also followed by even students' participation in speaking activity. The next was the high motivation in speaking. The last was students talked a lot in speaking class. However, from the scoring aspect, there were weakness and unsatisfied result of this research. The research was not successful yet to improve students' descriptive speaking competence into $60 \%$ of total subjects reached score $\geq 60$.

\section{DISCUSSION}

Although the using of cue cards to improve students' descriptive speaking competence in grade VIII 2 of SMPN 3 Bengkulu city could not achieve the level of satisfaction as expected, it did not mean that this media fail. The result showed that $56 \%$ of students were improved in descriptive speaking competence. This media can give the even opportunity to practice and develop students' descriptive speaking competence (Brown, 2004). The motivation of speaking 
was also increased because students know exactly what to say. Besides, the implementation of cue cards in speaking class proved that students became active and interested in speaking English as stated by Hamalik (1998).

Those finding was caused by several reasons. Firstly was students' focus on cue cards description was the big challenge. the grammatical competence of students was found as the second challenge in improving students' speaking competence. The last was students' vocabulary mastery limited students in describing pictures.

Many factors were involved in this case. The first factor was the insufficient capability of students in English especially speaking skill. As stated by Brown that speaking must consider some aspects such pronunciation, fluency and accuracy so that the action can be happened and understandable. While from the treatments and scoring, the students' score showed the lack capability in those aspects. Moreover, speaking was an interactive process of conducting meaning that involves producing, receiving, and processing information. This indicated that speaking cannot be separated from the other skills. Students in this class were not good in speaking could be affected by the lack of other skills as well. The fact showed that this class got troubles in full English explanation. But, these did not occur to whole class, the result showed 56\% students had the good foundation of English, and these students could be improved along the treatment.
Further finding regarding the factors influenced the improvement were: motivation, students' lack of dicipline, and students' attitude, inner motivation of students' toward English especially speaking interest. From two cycles, observer took notes that some students did not pay attention and did not study seriously in English class. These conditions worsened the understanding of students to the material given. In opposite, the research that was conducted by Suryani, 2010 was successfully improving student understanding in spoken descriptive because the motivation in speaking was high and what the previous researcher measured was the understanding of students to spoken descriptive text. So, the consideration between the previous and the current research was different.

The third factor was the lack of students' discipline along the treatments. Students did not work hard and cheat to each other. These affected negatively to students' progress. Group work without discipline and good control could not possibly create the chance for students to be dependent to smart students and dishonest in finishing the task. In additional as claimed by Harmer, the advantages of cue cards using is not to limit the typical class activities and writing exercises, students can as much spoken English practice as possible. But the fact found that students were not discipline along the class. The topic of speaking from students was often out of the cue cards focus and the use of 
English was mostly rare. The mother tongue was not clearly banned in English class.

The last problems occurred to certain students who did not join the treatments fully. Some of students missed the meetings while others did not participate in pre test or post test. This condition gave bad effects to the performance and progress. The real competence of those students in descriptive speaking could not be explored well. There was also underestimated attitude in descriptive speaking recording that showed by some students that influences badly to the performance and the scoring as the consequence.

Moreover, almost $80 \%$ of students' score increased in two post tests although the increasing was not as high as expected. The additional meetings would be absolutely able to fix the problems. Thus, the using of cue cards in improving students' descriptive speaking competence in grade VIII 2 of SMPN 3 Bengkulu city was not failed but the progress was not as high as expected.

As conclusion, the factors involved in improving students' descriptive speaking competence were the English proficiency that consists of integrated skills and language element such as pronunciation, grammatical comprehension, vocabulary mastery, and fluency. The second was the thinking ability of students to process the visual information into verbal and convey the meaning. Third was the attitude or behavior towards speaking activities that consist of motivation in speaking English, seriousness or fully attention, discipline, and the practicing time to drill the speaking skill.

\section{CONCLUSION}

The first objective of this research was to find out whether cue cards can improve students' descriptive speaking competence in grade VIII 2 of SMPN 3 Bengkulu city. While the other was to determine the factors those influence the improving students' descriptive speaking competence itself. After conducting the research, researcher was able to clarify that the using of cue cards is able to improved students' descriptive speaking competence with certain conditions and progress.

However, the factors those influence in improving students' descriptive speaking competence were English proficiency that consists of integrated skills and language element such as pronunciation, grammatical comprehension, vocabulary mastery, and fluency. The second was the thinking ability of students to process the visual information into verbal and convey the meaning. And the last was the attitude or behavior towards speaking activities that consist of motivation in speaking English, seriousness or fully attention, discipline, and the practicing time to drill the speaking skill.

As conclusion, the research showed that the using cue cards to improve students' descriptive speaking competence at grade VIII 2 of SMPN 3 Bengkulu city was an effective and practicable media. 


\section{SUGGESTIONS}

For the better implementation of this research, future researcher can consider some factors as follow:

1. Cue cards is good and suitable media in teaching descriptive speaking if only the condition of selecting and implementing the media can be fulfilled, such as students' capability in English, students' thinking ability, discipline and time allocation.

2. In implementing cue cards as the media to increase students' descriptive speaking competence teacher should put attention to build students' grammatical understanding that is useful in sentences construction to improve students' descriptive speaking competence by using cue cards.

3. To minimize the wrong pronunciations in speaking activity, teachers should speak English a lot to model the good pronunciation for students.

\section{REFERENCES}

Arikunto, Suharsimi. 2006. Penelitian Tindakan Kelas. Jakarta: Bumi Aksara.

Brinton,Donna M. 2001. The Use of Media In Language Teachings. In Celce-MurciaM, (ed.) Teaching English as a Second or foreign Language. $3^{\text {rd }}$ edition. Heinle \& Heinle.

Brown, H. Douglas. 2004. Language Assessment principle and classroom Practices. New York. Longman.

Budiastuti, Riana Eka. 2007. The Use of Cue Cards in Teaching Spoken Descriptive Text: The Case of Eighth Year Students of Smp N 13 Semarang. Unpublished Thesis in English Department Program, UNNES.
Hamalik, O. 1993. Media Pendidikan. Bandung: PT. Citra Aditya Bakti.

Harmer, J. 2001. The Practice of English Language Teaching (rev. ed). London: Longman.

Language Center, HKUST. 2004. Improving your Speaking Skill. retrieved 2000, from http://lc.ust.hk/

Lim, Patrick T.H. 2007. Action Research for Teachers: A Balanced Model (pp. 5-6). Singapore, from http://conference.nie.edu.sg/2007/paper/papers/O TH154.pdf

Ministry of Education. 2009. Supporting English Language Learning in Primary Schools. Wellington. Leaming Media Nation, IS.P \& Jonathan Newton. 2009. Teaching ESL/EFL Listening and Speaking. New York. Routledge.

Nunan, David. 2003. Practical English Language Teaching. Boston. Mc Graw Hill.

O'Brien, Rory. 1998. An Overview of the Methodological Approach of Action Research. Retrieved April 04, 2012 from http://CAR overview.html

O’Malley, J. Michael \& Pierce, Lorraine Valdez. 1996. Authentic Assessment for English Language Learner: Practical Approach for Teachers. London. Longman.

PW, M. Mursyid. 2011. English Learning Handout for Grade VIII. Retrieved February 8, 2011, from http://mmursyidpw.files.wordpress.com/2011/02/ learning-description.pdf

Sanrattana, Wirot.2007. Geoffrey E. Mills (2007) 3rd Edition "Action Research: A Guide for the Teacher Researchers". Doctoral Program in Educational Administration, Faculty of Education, Khon Kaen University. Retrieved in January 1, 2003 from: http: // ednet. kku. ac. Th / cedad/research article/Action_Research_Mills 2 $\underline{007 . p d f}$ 
Stevenson, Barry. (2003). MALT 2002-2B: Week 3: Understanding Action Research and Systems Session. [Word Document]. Retrieved May 22, 2003, from http:/l www. Jim force.cal malt action_research.pdf

Suryani, Lilis. 2010. The Use of Cue Cards in Teaching Spoken Descriptive Text (A Classroom Action Research on Seventh Grade Students in
SMP 15 Bandung). Unpublished Thesis in English Department Program, UPI

Ur, Panny. 1996. A Course in Language Teaching Practice and Theory. New York. Cambridge University Press. Wikipedia. 2012. Text Type. Retrieved May 14 2012, from: http://en.wikipedia.org/wiki/Text types 